\title{
Sacred Surplus and Pentecostal Too-Muchness: The Salvation Economy of African Megachurches
}

\author{
Asonzeh Ukah
}

[E]verything is plastic, even life itself DAVID CHIDESTER 2018:178

The beginning of the Christian Church is usually associated with the coming of the Holy Spirit upon the frightened followers of Jesus as narrated in Acts of the Apostle (Chapter 2). After Peter summoned courage to speak to the gathered "multitude", the story concludes that many of those who heard the word, believed and were baptised and were added to the church numbered "about three thousand" (Acts 2:41). Were this base community to be meeting weekly for liturgical purposes, it would have constituted the first Christian megachurch. However, for many reasons, the early church grew only slowly and met in small groups in members' homes and often clandestinely. The experience and the phenomenon which the concept of 'megachurch' encapsulates is as old as Christianity itself; nevertheless, the coinage of 'megachurch', like many other nomenclatures with the prefix 'mega' (such as megacity, megaton), is recent and of American provenance, and probably first used in a scholarly context in the late 1970s (Dubios 1978).

Mega - originally derived from the Greek megas meaning huge, and/or powerful - may have been the shortened form of one million (as a base of measurement), signifying an extremely large scale or excellent quality or sheer quantity. The megachurch denotes an excellent, great and successful church organisation or group. Its proliferation in Africa in recent decades signifies the appeal of its products to a large section of the African Christian population; its practices and organisational structure revolve around a principal charismatic figure believed to be a supplier of sacred or salvation goods who is cast in the mould of a profit-driven spiritual entrepreneur. In the context "of poverty amidst of plenitude at many levels" (Acolatse 2018: ix), the African megachurches - exclusively based in cities - sacralise the urban 
landscape by producing a sacred surplus - excesses and exaggerations of spiritual power and promises disseminated through modern mass media and commercial culture. Megachurches exemplify wealth and material success; however, paradoxically in Africa, they have blossomed in the context "where suffering, poverty and hopelessness is the order of the day" (James 2015: 12). This mix of wealth amid crushing misery adds to the complexity and contradiction of the megachurch phenomenon in the continent.

The megachurch is an organisational type rather than a theological category, although there is a dogmatic pattern of teachings and rituals of practice undergirding many of them. The religious and spiritual quest, which drives the appeal of megachurches, is intricately interwoven with certain organisational structure that enable them to reach and sustain the interest of many urban residents. Frequently defined as a Protestant congregation that averages about two thousand or more worshippers - men, women and children - meeting weekly for liturgical purposes (Ellington 2010: 247; 2013: 59), megachurches have evolved into their contemporary forms as a unique phenomenon of the modern, neoliberal era; they are examplars of organisational complexity, resource concentration, network density, socioeconomic strength and religiopolitical power. Among evangelical and conservative Christians (which includes some types of Pentecostal-charismatic ministries and churches), the megachurch represents the ultimate gold standard for success, influence and material grace in the Christian salvation economy. Since there is nothing intrinsically 'Protestant' about megachurches, Jonathan James (2015) extends the concept to include some Catholic parishes or Charismatic groups. This conceptual extension illustrates how dynamic, permeable and shifting the megachurch concept is. Similarly, in the African religious landscape, the megachurch experience may be extended to the indigenous Christian revivals of the early 20 th century. In the history of African Christian enterprise, the Zionist churches of southern Africa, the Aladura movement in West Africa and the Bakuzufu revivals in east and central Africa were the engines of Christian conversion and expansion (Kalu 2008: 26-39). Scale, size and prophetic magnetism were not just the driving force of these movements but the power of Christianity as a hugely popular and transformative socioreligious and cultural and geopolitical movement (Cox 2001 [1995]: 243-262; Peel 1968; Sithole 2016). Many of the revivals and the institutions they produced averaged well over the 2,000 worshipper benchmark of the megachurch. These revivals demonstrate how indigenous Christians rejected the received missionary model of Christianity and evangelism and evolved a culturally relevant, homegrown model of being Christian and building Christian institutions. 
In the last 150 years, no continent has changed in so short a time and so radically as Africa in terms of its religious demography. Religious transformation accounts for much of the speed and spread of social transformation in Africa. Writing for the Pew Trust in 2016 on "How Africa is Changing Faith Around the World", Philip Jenkins argues that Africa represents an ever-expanding demographics, a trend that will continue into the foreseeable future, and when combined with Africa's famed religiosity, will have radical consequences for the outward spread of both Christianity and Islam to other parts of the world, especially Europe. Europe's increasing secularisation throws into bold relief Africans' increasing religious significance because of increasing African migration, which coincides with the establishment of religious organisations by Africans in the diaspora. According to Jenkins, in Sub-Saharan Africa, Africans "favoured Christianity over Islam by a rate of 4-to-1". It is not surprising, therefore, that in the twentieth-first century, "Africa is home to some of the world's largest Christian.... communities" (Jenkins 2016). Many of Africa's largest Christian communities are organised as megachurches. These organisations are found in South Africa, Ghana, Tanzania, Kenya, Uganda and Nigeria (as well as across sub-Saharan Africa generally), where their presence continues to produce citywide spatial and ritual shocks. According to some scholars, these organisations are in the forefront of socio-religious change through their practices, rituals, social engagement and political activism (Asamoah-Gyadu 2015; Frahm-Arp 2016; Gitau 2018). For some of these congregations, "even the term 'megachurch' seems an understatement" (Jenkins 2006: 91).

As the study of Tomas Sundnes Drønen (2013) in northern Cameroon illustrates, Pentecostal churches in Africa usually start as prayer meetings of a few persons but with the intention of expanding to become megachurches. The intention and aspiration to have received a "sacred mandate" to disseminate the gospel to the entire world impregnate their activities and provide a rationale for the engagement of strategies of growth and expansion such as revival and evangelisation enterprise, mass media, market strategies and commercial practices (Asamoah-Gyadu 2015; Ukah 2016a: 665-683). Few achieve that aspiration, many remain midsized and modest. Within African Pentecostalism, size and scale - that is, becoming a megachurch - is a definitional feature of Pentecostal success. Therefore, for many church founders and owners, mass appeal defines and reinforces the truth of the message preached, and is the material proof of divine approval. Frequently, African Pentecostal leaders and church founders look towards American religious life and culture for examples 
to emulate in church building, organisation and the modelling of salvation goods.

However, while some African megachurches emerged as a direct contact and assimilation of the North American model of church growth or new paradigm churches, some are home-grown and nurtured. As indicated above, the 1920 and 1930 sere the decades that the seeds of megachurches were sown in Africa; the 1970 and 1980 s were decades when they blossomed under the contexts of extreme economic challenges and political instability. This period also coincided with the expansion in literacy through the establishment of formal education infrastructures such as universities, teacher training institutes and polytechnics. The increase in transnational travels and mass communication system facilitated the interpenetration of religio-cultural influences and other foreign ideas and lifestyles. In Nigeria, which has been described as "the Pentecostal locomotive" in Africa (Drønen 2013: 3), Immanuel Olufunmilayo Odumuso (1915-1988; also, popularly called Jesu Oyingbo by his followers) established the first megachurch, Universal College of Regeneration, in Lagos in 1950s (Onishi 1998). He built an expansive commune or religious enclave where nearly a thousand of his followers lived and worked in supporting industries he owned such as bakeries, restaurants, real estate companies and barber shops. At the peak of his organisation, he had more than 2,00o followers and seekers of spiritual favours who congregated weekly at this commune at Manor Street in Lagos for religious activities. Apart from teaching his followers his own interpretation of the Bible which he claimed he received through direct revelation from God, he developed his sacred industry and empire to become the first pastorpreneur and manager of the first megachurch in Nigeria. Trained as a carpenter and worked in the Department of Post and Telecommunication, Lagos, Odumosu declared himself to be Jesus-come-back-to-life in June 1959:

I am He. I am Jesus Christ, the very one whose second coming was foretold in the New Testament. I have come, and those who believe in me will have an everlasting life and joy. I am the missing of the trinity. I have come to prepare the faithful for the judgment day. ${ }^{1}$

What is important in this historical origin is that what developed as megachurches in Yorubaland of Nigeria often involve what JDY Peel (2016: 214) describes as the three circles of Yoruba religion: the diffused strands of Yoruba

1 Austin Oyibode, "How Jesu Oyigbo, a Self-Acclaimed Jesus in 1970s, Raised his empire and died in 1988 in Lagos", https://www.naija.ng/1106645-how-jesu-oyingbo-a-acclaimed-jee sus-1970s-raised-empire-died-1988-lagos.html\#1106645. Accessed 07/07/18. 
traditional religion, the strands of Christianity and Islam practised by many Yoruba and religion of Yoruba origin practised outside Yorubaland "by people who are not Yoruba" (2016: 215). The circles that Peel identifies may be likened to phases and layers of translation of religion from one culture to another, from one epoch to another.

African Megachurches often develop from the African Independent Churches (AICs). ${ }^{2}$ The AICs initiated the processes of cultural appropriation and adaptation of the gospel to local needs and desires. They also produced the personalities and ideas which have been of interest to megachurch founders. In some historical instances, some AICs morphed and transformed into Pentecostal churches before expanding and diversifying into megachurches. The megachurch phenomenon in Africa, therefore, represent a phase of translation of Christianity, first from mission Christianity into African indigenous Christianity and then into Pentecostalism. Once this final stage is achieved, the popularity of sacred goods and services (doctrines, miracles, personalities and rituals) and the aggressive use of media technologies frequently produce megachurches. As a translation phase, African megachurches can be conceived along many dimensions of translation: the first being from the AICs to the more contemporary form of organisational style, and the second is translating global Pentecostal new paradigm organisational culture and objective to local-cultural context and desires. Megachurches become what they are because they creatively respond to local religious desires and tastes.

\section{$3 \quad$ Plastic Spirituality}

African megachurches represent the plasticity of the religious worldview and practices that characterise contemporary modernity and culture. According to Virginia Gerrard-Burnett (2015: xii), megachurches are imbued with "theological plasticity [which] allows for considerable innovation and cultural adaptation from one place to another". African megachurches exhibit more than theological plasticity; they embrace historical, structural and strategic plasticity. Recognising that "plasticity signified everything important in the imagination of matter in the twentieth century [because it] seem to define the contours of a religious world" (Chidester 2018: 177; 178), this feature more than aptly captures a fundamental aspect of the social worlds of megachurches, especially as they manifest in the African lifeworld where the dynamics of rapid social transformation compel organisations to respond quickly or whither ultimately.

2 The "I" in AICs would also mean Instituted, Indigenous, Independent or Initiated. 
David Chidester (2018:178) relates the interpenetration and borrowing between religious groups and popular culture, arguing that "religious groupings seek to mold the plasticity of ...ppopular culture in the service of their own religious interests". As a new form of organisation style, the African megachurch converts rigid ecclesiastical and administrative structures into fluid and permeable, even protean, network. Ecclesiastical plasticity allows church founders to morph into religious entrepreneurs and innovators, to translate and transform religious and cultural ideas and habitus and imbue them with the aura of the sacred. Religious plasticity accounts for how older spirit-led churches transformed over time into large Pentecostal organisations by incorporating aspects of corporate, financial, economic and social features they consider useful for their survival and flourishing. There are many examples of these organisations in Africa; one will be discussed in some detail to illustrate their strategies of expansion and elasticity.

Arguably the largest megachurch in Africa is the Redeemed Christian Church of God (RCCG). It is an organisation that perfectly fits into the prosperity, miracle-producing church. Founded in Lagos in 1952 by Josiah Akindayomi, a prophet of the Cherubim and Seraphim Church (C\&S), one of the main Aladura churches originally established in 1925, the RCCG has morphed into a religio-economic and a quasi-political organisation. Akindayomi was a prophet-healer and the organisation he founded was in the tradition of "spirit churches", small-scale spiritual enclaves that believe in mobilising the power of the Holy Spirit in solving quotidian human problems, especially those concerned with bearing children and dealing with negative mystical forces (such as witchcraft and sorcery), etc. Within a decade of its founding, the RCCG started shedding its Aladura cloak and aura by adopting the doctrines from Four Square Gospel Church and using the Sunday School Manual of the Assemblies of God Church. The urgency to drastically but spectacularly separate itself from its past led the group to affiliate to the Apostolic Faith Mission (AFM) of South Africa, one of the earliest (and mega) Pentecostal churches in Africa. The AFM has a direct missionary root that leads to the Azusa Street revival of 1906 (Frahm-Arp 2016: 262). By the late 196os, the RCCG had fully pentecostalised and disaffiliated from the AFM. In the post-war era of 1970s, the church had become a world-rejecting, pietistically strict, holiness type of organisation. When Akindayomi died in November 1980, the RCCG was still small and provincial, mainly found in the suburbs of Ebute-Metta, a backwater area next to the Lagos lagoon, and far from being a megachurch.

Transmuting the RCCG into a megachurch was the responsibility of Enoch Adejare Adeboye, a senior lecturer with a doctorate degree in mathematics at the University of Lagos, and later at the University of Ilorin. To lure urban, 
upwardly mobile and educated youth into the church, Adeboye converted the rigidity of Akindayomi's holiness ethos into the plasticity and elasticity of neopentecostal prosperity doctrines, practices and structure. His first step in this direction was to jettison the Sunday School Manual inherited from the Assemblies of God, crafting a new one for the church imbued with the new spirit of elasticity and malleability of prosperity Pentecostalism and its propositional attitude. New structures of ritual, administration, attitude to money, acquisition, business, politics and the state were the areas that the new leader, like an alchemist, (re)instituted in the RCCG. By the 199os, and at the peak of the harshest and most brutal military dictatorship in the history of Nigeria, the RCCG blossomed into a megachurch as politicians and business people seeking both personal safety, financial security and political relevance flocked into the church. By the 2000s, the RCCG has become the most important, the most populous and the wealthiest religio-economic corporation in Nigeria, owning "the largest private estate in Nigeria" and "arguably the largest Christian Estate in the World" (Bible-Davids 2009: 147; 146). In 2018, the 2,80o-hectare Redemption Camp is home to the largest ritual infrastructure in Africa, an auditorium measuring three square kilometres, proudly called "Heaven-onEarth" auditorium by officials and with a sitting capacity estimated at 3 million worshippers. ${ }^{3}$ The Camp, which hosts three important activities for the church (monthly Holy Ghost Service, annual Holy Ghost Congress, and Annual Convention), has a permanent residential population of about 30,000 believers. To grow into a megachurch, the RCCG under Adeboye invented new rituals, modified doctrines and incorporated practices from the United States, South Korea and the corporate culture of commercial advertising and marketing. It also changed its attitude towards money, conspicuous consumption, ostentatious display of wealth, acquisitiveness, politics and the state. With separate congregations in more than 192 countries in 2016, the RCCG is redefining the meaning of a megachurch, and transcending boundaries to become a metachurch: a massively convoluted and byzantine sacred corporation that blurs the boundaries between religion, politics and economics in its attempts to meet popular desires and provide personal and corporate care and nurture for individuals and groups. In Africa, the RCCG in its ginormous global selfpositioning defines and spectacularises (through mega-sized projects and gathering of multitudes for worship, etc.) the new paradigm of Pentecostal megachurch success, demographically, economically, and politically (Ukah 2018).

3 Information sourced from the Director of Physical Planning at the Redemption Camp $(19 / 07 / 16)$. 
The history and trajectory of the RCCG capture a fundamental thrust of many African megachurches. They start as small house fellowships, and each decade they morph into a different organisation, theologically, administratively and behaviourally. The Living Faith Church Worldwide, (A.K.A. Winners' Chapel) started in similar circumstances in 1983. The founder, David Oyedepo, was born into Cherubim and Seraphim church. He got exposed to PentecostalCharismatic spirituality and practices as a student in a polytechnic. He layered his experience with American prosperity doctrines claiming that "In the summer of 1987, I was in far away in the United States of America.... when I had a unique encounter with God.... saying: 'Arise, get back home and make my people rich'" (Oyedepo 1997: 14; 2008: 7). Interpreting 'home' as not Nigeria but Africa "where most people live below the poverty line" (Oyedepo 2008: 7), Oyedepo made prosperity the undeniable proof of his mandate, legitimacy and authority. While the RCCG is the wealthiest religious organisation in Africa, Oyedepo is the wealthiest Pentecostal pastor in Africa, according to a recent Forbes publication, with an estimated personal worth of US $\$ 15$ omillion. ${ }^{4}$ Temitope Balogun Joshua, founder-owner of the Synagogue, Church of All Nations (SCOAN) is by far the most controversial megachurch prophet in Africa. While he was born into an Anglican family, as he grew, he became involved in the Aladura spirituality before establishing his own church in 1986 (Ukah 2016b: 220-222). As the foremost supplier of spiritual healing and prophecy in Africa, T.B. Joshua's SCOAN is a massive, media-embedded megachurch with average weekly ritual attendance of 15,000-20,000 (Ihejirika and Okon 2015: 68). Joshua is the greatest personality at the centre of the largest religious tourism industry in Africa, attracting more than half a million miracle-seekers to sCOAN's Lagos headquarters each year. In these examples, African megachurches' plastic features enable them to migrate from one church type to another, each time maximising the advantage of numbers as an index of legitimacy, popularity, power and authority.

\section{Producing Popularity: Types of African Megachurches}

Megachurches are religious organisations that have successfully mobilised and accumulated resources from its environment. The extent that a religious group is able to do this determines whether it grows or stagnates (Innaccone et

4 https://web.codedwap.co/2018/01/o6/see-forbes-richest-pastors-africa-2017-2018-see-list. html. Accessed 11/07/18. 
al. 1995). In many African societies, religion is recognised as a 'public good', an institution and practice of common purpose and good free from taxation and government interference. Typically, megachurches strive on the assumption of creating a public good - goods that supposedly help build individuals, and in so doing, develop communities and advance the public cause. Producing salvation goods of public interest makes a religious organisation a popular social institution. According to Martin Riesebrodt (2010: xii), the foundational meaning and purpose of religion are to be found in its promises and concerns "with warding off misfortune, coping with crisis, and laying the foundation for salvation". For Riesebrodt, "Religions promise to ward off misfortune, to help cope with crisis, and to provide salvation", and so are less about the sacred or holy and more about "the providers and mediators of salvation" (Riesebrodt 2010: xiii). The provision of these religious goods is the means through which megachurch leaders engage with the public, a method of being in the world, and in many instances, of the world. The way that charismatic figures and spiritual entrepreneurs provide these goods of salvation make them and their institutional frameworks for the dissemination of these goods popular. Megachurches emerge through the production of popular religious cultural materials and services. Innovation and consistency in such production and distribution of religious goods enable them to achieve a statistical weight of popularity.

African megachurches resolve around a charismatic figure or centre, a person who claims an above-normal endowment of sacred power that warrants her/him to be a powerful, privileged and, therefore, regarded as 'bigman' or 'bigwoman' of a 'big God', with a guranteed access to the goods of salvation. Charismatic power, as Max Weber (1992[1922]: 47) makes clear, demands constant "charismatic authentication" and "validation" which comes through the performance of "miracles or magic". Creating goods and services of salvation that appeals to a large number of people is necessary for the construction of megachurches. Such goods and services (mainly, healing, deliverance, miracles of prosperity, religious knowledge) are frequently construed as the credentials that guarantee credibility and legitimacy of the megachurch pastors. These goods have reputational function for the producers; they create a market niche for each producer and cultivate such a clientele over time. A viable market niche creates a population concentration in the religious market where choice and options, like desires and tastes, proliferate. While not discounting the evangelistic zeal frequently framed as a global enterprise, specific strategies and stratagems cannot be ignored in understanding patterns of growth and branding among African megachurches. Asamoah-Gyadu (2015: 58), writing about the reasons for growing a megachurch in Ghana says that "many of the reasons are simply for practical, financial, and other material resources", in 
addition to the socially worthy reason of saving the unsaved, bringing in sinners into the kingdom of God.

African megachurches produce goods and services that many urban dwellers consider desirable. Depending on what goods of salvation these organisations produce and disseminate, they can be broadly divided into four types, namely: (i) Prosperity Megachurches, (ii) Healing and Deliverance Megachurches, (iii) Personal Empowerment and Apostolic teaching Megachurches, and (iv) Prophetic-Healing Megachurches. These divisions are ideal types and in many cases, there are overlaps among them. For example, there are some megachurches, such as the RCCG, that combine many of the features of some or all four aspects or qualities of these sacred corporations. In practice, it is safe to hold that different megachurches manifest different traits or combination of traits to a lesser or greater extent.

\section{i) Prosperity Megachurches}

Prosperity Pentecostalism which emphasises the importance of personal success in the life of a born-again Christian is by far the most popular Pentecostal tradition in Africa. Prosperity megachurches premise their popularity on the claim and promise to produce financial and material success - construed variously as dominion, promotion, wellbeing - for their members. Winners Chapel, for example, falls into this category. As the single most important exponent of this type of teaching, David Oyedepo, the founder of Winners Chapel, often self-identifies as a prosperity teacher; sometimes, however, he prefers calling himself a 'prophet' with a prosperity message. He founded Winners Chapel on 23 September 1983 as a fellowship group (named Faith Liberation Fellowship Hour) in Ilorin, Nigeria. In September 1985, the fellowship was relocated to Kaduna, where Sunday services were introduced as well as the new name of Living Faith Church Worldwide. There was an initiate growth which resulted in Oyedepo being consecrated a Pentecostal bishop of Northern Nigeria by Archbishop Benson Idahosa and other leaders of the Nigerian Pentecostal Fellowship in 1988. After 1992, further expansion was stymied forcing the founder to relocate the headquarters to Sango Ota in Ogun State, neighbouring Lagos. The church soon experienced a runaway expansion and in 1998 opened a ritual facility, Faith Tabernacle, originally on a 560 -acre property, which has since expanded to measure about 5,000 acres. The Faith Tabernacle has a capacity of accommodating 50,000 worshippers and was advertised to be the largest ritual facility in the world at the time. Winners Chapel has branches in more than 65 countries mainly in Africa, Europe, North America and Asia. Oyedepo runs Winners Chapel as a sacred corporation and positions himself as a Chief Executive Officer - and his wife, Faith Oyedepo, as company secretary - of his 
religio-economic empire. Members of his corporation are obligated to buy his books and sermons each week as a material sign of being in fellowship with him. Oyedepo is at the head of a massive self-publishing media empire, Dominion Books, as well as Bible Schools and three universities (and plans to establish four more in different parts of Africa) (Ojo 2006: 164-167). Covenant University, owned by Oyedepo, charges the highest tuition fee, second only the to Baptist-owned Bowen University, in Nigeria. Dominion Publishers has also printed and marketed more than 4 million copies of books written by Oyedepo. Each week, Oyedepo identifies three of his books and instructs his followers to buy and read them as a way of remaining in a divinely-assured prosperity network. To underscore his special claim to divine intention, he recommends his publications as more powerful than the Bible: "You can read the Bible from now till Jesus comes, and still not get a light from it! But locate a man whom God has sent, camp around him, begin to swallow his words and you will soon find something that will loose you from the chain of poverty" (Oyedepo 1997: 154). The church is also an active player in the real estate sector in Lagos and Abuja where cumulatively it is building more than 200,000 housing units of various sizes for sale to rich members of the church. As the wealthiest of all Pentecostal pastors in Africa, Oyedepo owns four private jets as a validation of his gospel of wealth and health, a symbol that appeals to many people who view him as a role model for achieving prosperity and so join the church.

\section{ii) Healing and Deliverance Megachurches}

The second subtype, healing and deliverance megachurches, is also very popular because through their practices, they aspire, even claim, to reconstruct religion as a technology that responds to the daily needs and experiences of spiritual and physical insecurity which many Africans confront on a daily basis. Culturally, healing is a key aspect, and function, of religion in the African worldview. Liberty Gospel Church (LGC), founded by a self-acclaimed former witch, Helen Ukpabio, in 1990 has as its special focus, the deliverance of those who are under the bondage and torment of witchcraft possession. With more than 80 separate congregations in five countries and with its international headquarters in Calabar, Cross River State of Nigeria, LGC specialises in the production and dissemination of witchcraft deliverance services through mass, trans-denominational events held in sports stadia as well as popular video-films (Ukah 2012; Ukah and Echtler 2009; Ukpabio 1999). Better known for her movies and books on witchcraft than for her status as a megachurch founder, Ukpabio is constantly embroiled in controversies surrounding the social implications of her teachings on witchcraft which many social activists link to instances of child abuse based on accusations of occult power. The 
Universal Church of the Kingdom of God, which is very popular in southern Africa (Van Wyk 2014; Frahm-Arp 2016: 275-279) (and has spread to Lagos in recent years), and the Mountain of Fire and Miracles, with headquarters in Lagos, are some of African megachurches whose special brand of product is the provision of interventionist services and practices (Riesebrodt 2010: 92117) which promise to avert misfortune believed to be caused by malignant spirits. Part of the success of this group of megachurches is the relentless scrutiny of the indigenous religious worldview where negative forces are challenged and purportedly deconstructed with the power of the Holy Spirit or the "Blood of Jesus". The strength and popularity of these churches are in the diverse ways in which they engage with indigenous African spiritual epistemology and agency, making them relevant for contemporary life situations.

\section{iii) Personal Empowerment and Apostolic Teaching}

Pentecostalism is a power religion. It makes huge claims to empower the believer through the actions and the indwelling of the Holy Spirit, which enable the believer to "do greater things" in this world (John 14:12). Especially in the fraught and disempowering circumstances in which many Africans live, churches and religious leaders who promise to reverse the trend and provide a relevant religion, usually secure a market niche for their goods. Some churches that claim to provide such services of empowerment through teaching correct doctrine (as against performing or producing miraculous interventions) and so brand their goods have achieved success in mobilising social resources, mainly numbers: consumers, clients and patrons. The youth, who may be struggling to define a path for their future and generate social networks, often find this type of organisations very appealing. Worship Harvest Ministries (WHM) in Kampala, Uganda, represents this group of megachurches in Africa. The WHM claims to provide a relevant religion that retools the youth with a purpose in trying urban spaces where they struggle to make a living and achieve a sense of personal meaning.

Founded in 2005 by a musician and professional architect, Moses Mukisa ${ }^{5}$ and some of his fellow musician-friends, the WHM started off as a religious popular cultural space where young people hungry for something unlike institutionalised religion could experiment with being religious according to their aspirations. Accordingly, the first meetings of the group started in a drinking

5 Like David Oyedepo of Winners' Chapel, Musika studied architecture at the Makerere University on a government scholarship. Before founding wнм, Musika worked with Kiggundu and Partners (later known as Arch Forum Ltd.). He later founded his own company called Living Space which specialised on Innovative Designs. 
bar, a secular and entertainment environment, where young people could be themselves and relate to the supernatural as they were rather than as prescribed by some religious elite according to some ritual, coercive orthodoxy. With eight branches, called 'locations', and an average cumulative membership of more than 2,500 bona fide members, the WHM is under the youthful leadership of Moses and Sarah Mukisa, supported by seven other couples. The WHM does not call itself 'church' but as "a movement of the Gospel, discipleship and mission, catalysing spiritual, social and economic renewal in our immediate communities and as a result the world". 6

Music is a strong resource and appeal of the WHM that has enabled the group to achieve social visibility, popularity and viability; its theology of a fluid, relevant religion - devoid of coercive structures and theologies - that repurposes the youth to engage with spiritual, social and economic renewal in their immediate surrounding has found resonance among the young people of Kampala and its satellite towns. The reinterpretation of salvation into leadership renewal for urban redevelopment has been a strong pillar of attraction and success of the WHM, according to the vision of its founder. Mukisa's experience of growing up as the last child in a large family of six siblings and brought up by a single mother on a teacher's salary in rural Uganda serves as the usual staple of 'from grass to riches' that attracts young people hungry for success. Musika's special prayer before sitting for his exam symbolises the yearnings of many young persons who feel helpless (although hopeful and spiritually restless) but crave to be enrolled on "God's scholarship" for a successful adult life:

God help me, because my mum is now out of the picture. If I don't pass, I don't know anyone who is going to take care of me. If I don't go to the university on [a] government scholarship, this is the end. ${ }^{7}$

The entire church serves as an academy for a new type of leadership for the youth to redefine and remake their destiny and future (through acquiring the proper religious truths). The importance of leadership training and modelling in WHM is the founder's belief that the African continent's singular predicament is related squarely to its leadership deficiency, a problem that afflicts and is manifested in all strata of society, government, religious organisations and the economy. According to a middle-aged female member of wHM, "I attend

6 http://www.worshipharvest.org/ (14/07/18).

7 "An Architect, a Pastor, and a Gospel Artiste", Daily Monitor (Kampala), 04/12/10, http://www .monitor.co.ug/SpecialReports/success/859508-897336-m8gx93z/index.html (14/07/18). 
WHM because it isn't too structured and conventional. Rules are made up as [we] go along. [The church] accepts people for who they are, and they accept people as they come". ${ }^{8}$ Although megachurches symbolise strength and sturdiness, these features are balanced with and by flexibility and structural plasticity as indicated by this worshipper.

\section{iv) Prophetic-Healing Megachurches}

The last group of megachurches is those that focus on the delivery of prophecies as an important but scarce service in contemporary Africa. In recent years in Africa, a new prophetic elite has emerged whose activities straddle the religious and political domains because of the nature of the followership and the goods of salvation they claim to offer politically exposed and powerful people. Even when they disavow any direct involvement in politics, they are political prophets in more ways than one: they service political actors, supply prophecies with direct political significance and consequences, mobilise resources (mystical and human) for political participation and intervention. The search for insights into the future is strong among contemporary Africans who increasingly grapple with existential uncertainty and vulnerability caused by, among other factors, rapid social change and structural weakness of the postcolonial African state. Prophecy delivers a degree of confidence and certainty to confront and navigate myriad of existential instabilities and muddles. Prophets who claim divinatory powers of searching the mind of deity for surefooted directions for practical action often attract large followings from all strata of society. The preeminent prophetic megachurch in Africa is SCOAN (mentioned earlier), whose ever-controversial prophet, T.B. Joshua, has elevated global prophecies to a never-before seen level. With the power of modern communication technologies such as the Internet and satellite television broadcasting, Joshua and his Ikotu, Lagos-based church provide services that are in demand all cross Africa and Asia. These services are frequently broadcast live to different global locations through Emmanual Television, the satellite broadcasting network founded and owned by Prophet Joshua, reaching several million viewers weekly. Joshua's influence is felt in east and southern Africa when many church founders model their self-image and products after their virtual mentor (Joshua).

Unarguably the largest megachurch in Kenya is the Ministry of Repentance and Holiness (MRH) established by Prophet David Edward Owour in 2005. ${ }^{9}$ Born in 1966 in Goma village in Bondo District, Owour was the second of six

8 Personal interview with wHM member, Kampala, 29/07/17.

9 In his scholarly publications, he uses the name Edward D. Owour. It is not clear why he adopted for "David Owour" as his prophetic name other than David is a powerful biblical figure, 
children (three girls and three boys). His parents, Hezekiah and Margaret Ochieng, were devout Christians. He started his tertiary education at the University of Makerere in Kampala but later changed to the University of Nairobi where he obtained his Bachelor of Science degree in 1988. He proceeded to Ben Gurion University of the Negev in Israel in 1992 where he obtained his master's degree and later to University of Haifa, on Mount Carmel, where he graduated with a doctorate in molecular genetics. His academic credentials include a postdoctoral fellowship at the Centre for Pharmacological Biotechnology at the College of Pharmacy at the University of Illinois, USA, and later worked as a professor of medicine at the University of Oklahoma. From 2003, he claimed to have had his inaugural vision and prophetic mandate in a series of special visions of God in the company of Daniel, Elijah and Moses (as witnesses) and receiving a mandate to be the "Hand of God on Earth". He further claimed that in a vision witnessed by John the Baptist in 2004, God appeared to him and handed him the Rod of Moses so he could preach repentance to all the world and prepare humankind for the Parousia. He is both respected and feared by ordinary Kenyans and politicians alike who accord him utmost respect and dread. He criticises established Christianity, especially the Prosperity Pentecostal variant; he, therefore, fails or refuses, to establish any cooperation or network with other major churches. He also has a "love-and-hate" relationship with Kenya's political elite whom he accuses of every known sin; yet, he blackmails them to participate in his city holiness revival or risk being voted out of office during elections. His primary products are holiness or repentance, prophecy, and healing. The MRH is as unusual as its founder. It is not called a church as Owour is hugely antagonistic to established religion and religious nomenclatures; it is called "tent" and so, is technically a 'megatent', rather than a megachurch. Owour's symbolic white suits and white limousines, characteristic prophecies of darkness, gloom and doom and the unparalleled capacity to mobilise multitudes of people to shut down different parts of Nairobi set this 'megatent' and its founder apart from other megachurches. His 'radical Otherness' and promises of healing and holiness draw many to his services.

In building a robust organisation, expanding membership is key. However, even for Pentecostal groups that claim to open their doors to anyone and everyone, it is only a matter of time before they become strategic in deliberately

a builder of God's temple and a prophet, see: http://www.repentandpreparetheway.org/ (14/07/18). It is also unclear how Owour recognised these biblical personages. 
targeting the wealthy and upwardly mobile segments of a society. While the poor may constitute the numerical base and strength, the wealthy and educated form the financial backbone and intelligentsia. The demographic and quantitative definition of the megachurch highlights its implication on the popular religion as popular culture (Chidester 2018: 166-173). A megachurch is a popular religion, an organisation that prides itself on producing and marketing services, goods and ideologies that many people like and consume. It produces salvation goods on a large scale, creates complex networks and channels to distribute these to a large religious consumer market; its economy of scale activities means that its products are "regularly consumed by large numbers of people" (Chidester 2018:167). African Megachurches are deeply embedded in the production and consumption of religious popular cultures such as religious movies, sermons encoded on DVDs and CDs, books and pamphlets, SMS and daily devotionals (Ukah 2008: 150-151). They engage in relentless exchange processes whereby they borrow technology forms and cultural formations from the larger society while (re)encoding these with their own contents and interests. Their media production includes radio and television stations especially satellite and Internet broadcasting where their major products are miracles of healings, testimonies, and teachings or motivation talks (Ihejirika and Okon 2015). Through these means, they (re)enchant the large society.

Therefore, the different types of megachurches as discussed above are spaces of, and for, public enchantment. According to the art historian, David Morgan, although enchantment comes from the Latin cantere, to sing, its meaning revolves around being spell-bound and rooted like a marble statue (Morgan 2018:1-3). It is "the subordination of a network to a focal object" (Morgan 2018: 78). Megachurches are possible because of their power to subordinate a large network of persons to a core sacred focus or object, the charismatic figure, who is the supplier of goods of salvation: healing, repentance, prophecy, empowerment, enlightenment, prosperity and success. Through their activities, or rather, products, which may take place all week-long and may cover different aspects of life, megachurches sacralise urban centres where their influence and power are focused and intensely felt. Rituals are special structures of enchantment; they are performative practices that are moulded towards approaching the sacred and at the same time resacrelising the self in the process. African megachurches' strategies of expansion include the restructuring of (urban) space and time. For example, the construction of prayer retreat sites, popularly called Prayer Camps, is one of these strategies. The RCCG, for example, holds its most important trans-denominational event monthly; the first Friday of each month is when the Holy Ghost Service, an all-night prayer and miracle service holds. The HGS gathers together more than 200,000 worshippers at the 
Redemption Camp for prayers and miracles. The first weekend, unlike other weekends of the months, is unusually sacred. Enoch Adeboye, who is the inventor of this ritual, claims the choice of the first weekend was informed by divine instruction: this is when God wants to perform miracles and answers the deepest yearnings and desires of worshippers. It has to be a night vigil because God is keener to hearkening to the prayer requests of people during the stillness of the night. However, Friday night is important because many people will be free from working on Saturday morning; likewise, first Friday of the month is important because salaries and wages are paid during the last week of the month, just days away from the first Friday of the month. Staging this event in this way better maximises both attendance and fiscal extraction. This event restructures this time of the month and ritualises the site where it is held.

Because the RCCG has chosen the first weekend of the month for its event, the Mountain of Fire and Miracles (founded by Daniel Olukoya in 1989), another megachurch, which runs a sprawling prayer camp just 20 kilometres away from the Redemption Camp, holds its version of monthly night vigil, called "Power Must Change Hands" ( $\mathrm{PMCH}$ ), every first Saturday of the month at its ritual camp, the Prayer City. This camp is described as a site where "aggressive prayer goes on 24 hours a day, 7 days a week, non-stop". ${ }^{10} \mathrm{PMCH}$, like HGS, is broadcast live on YouTube and satellite Television channels. ${ }^{11}$ Similarly, the Christ Embassy, another 'super-megachurch' with headquarters in Lagos holds its monthly vigil on the last Friday of the month. To maximise both influence and extractive capacity, these monthly events are also conducted at all branches of the megachurches outside their national headquarters or Camp. Furthermore, they have been exported aboard wherever the organisation has a congregation. Monthly night vigil has proliferated among megachurches as both a pillar in their salvation economy and a structure in the enchantment of urban space, time and imagination. Further, it is a means of exercising spiritual influence among believers, for those able to attend as well as those who are unable to attend but are advised to watch them live online, on satellite television channels and on their mobile phones. Undeniably, these events, which indicate excess of sacred goods, constitute a veritable means of foisting and fostering an enchanted imagination on religious and urban publics.

African megachurches use technologies to produce and sustain urban enchantment. These organisations, like other Pentecostal-Charismatic Churches, are savvy users of modern communications technology as instruments of

\footnotetext{
10 https://www.mountainoffire.org/about (15/07/18). In addition to the monthly vigil, the MFM holds "Prayer Rain" event every Friday from o8hoo.

11 https://www.mountainoffire.org/pmch (15/07/18).
} 
enchantment. As described in the four types of African megachurches, each of the founders has used technology in a specific way to shape and influence the public in a way that supports his or her interpretation of the scriptures and charismata. The scriptures as power instruments are technologies that extend the influence, power, authority and legitimacy of religious entrepreneurs. As Joyce Smith (2008: 151) makes clear, media producers have both good and greedy reasons for the way they use media to influence specific publics. For the managers of megachurches, the media work in diverse ways to keep their audiences, customers, consumers and clientele enchanted so that numbers do not drop, and influence or finances do not shrink.

African megachurches are not modern innovations; they have been in existence for decades although their forms have been changing from decade to decade. They are characterised by the feature of adopting a complex range of theologies and structures as a strategic self-positioning relative to the larger society and the religious or spiritual desires of segments of society. This complex range of social and theological positions within the production, circulation and consumption of religion has become necessary in attaining and maintaining their mega-status and withstanding stiff competition in an increasingly crowded sacred (and entertainment) market. Megachurches are structures of materialising power. They constitute a social aspect of Pentecostal too-muchness, the desire, and greed as some scholars may prefer to regard it, to accumulate and manifest material excess of charismata, organisational structure, possession, wealth and influence. The grandiose promises and expectations, the hyperboles and extremes of thriving for everything are materialised and spectacularised in megachurches and megatents. Megachurches are paradoxical organistations in the African socio-economic and political landscape: As Africa experiences too-muchness of poverty and deficiencies of social infrastructure, the continent is likewise experiencing the emergence of Pentecostal too-muchness, increase in mega-sized churches with a dizzying accumulation of wealth, power and property. As Asamoah-Gyadu (2015:58) contends, African megachurches are frequently motivated by greed for finances and fame. In this regards, money, as a system of storing, recording and calculating value ${ }^{12}$ is the fuel of megachurches; chronicling their emergence and

12 Megachurches also recognise that money is a system of value transfer and evaluation; hence, the stress on money-making, donation, tithing and giving, etc. 
performance, as this chapter has attempted to do, is a way of scrutinising the nature and performance of power. In diverse ways, all megachurches are performers of power and money. They are entrepreneurial powerhouse organisations where religion, entertainment, popular culture is legitimated, reinforced and fused with for-profit discourses and practices. Even here, as in its theology and biblical interpretations, the plasticity and fluidity of African megachurches is very evident.

For megachurches, number is sacred; it is more than destiny: it is (organisational or institutional) salvation. In the democratising countries of Africa, the numbers that megachurches can generate has afforded them tremendous political attention, attraction and power. With only a few exceptions, almost all African megachurches play direct and indirect political roles. The political behaviour of these churches indicates that they exchange sacred bonds with the political class who use the platforms of mass ritual events as strategies of image laundering in exchange for political patronage. Owour of Kenya receives political and diplomatic privileges from the Kenyan State which includes money; the RCCG is beholden to the political elite of Nigeria and has received import tax waivers amounting to several million United States dollars; SCOAN is host to several high-ranking politicians from several African countries including Zambia, South Africa, and Ghana. Founders of some of Ghana's megachurches are appointed into boards of government establishments including universities in exchange or as a reward for their support of government policies and practices. Across Africa, therefore, the general trend is that the megachurches are pro-state establishments from where they receive massive financial and symbolic supports; they frequently host political and state actors. This alignment to the status-quo and support for oppressive, extractive and sometimes predatory postcolonial structures and actors not only dent the social image of these megachurches and embroil them in political controversies, it also vitiates the often-vaunted capacity to introduce sustainable and long-lasting social change in their immediate societies. Furthermore, because megachurches are not democratic, transparent and publicly accounting and accountable organisations, they lack the culture that inculcates in their members democratic values of demanding for political and ethical accountability from politicians, public officials and the state. Consequently, they are hardly suitable spaces for members' training for citizenship rights, political responsibilities and obligations. While the African megachurch republics have built impressive religioeconomic corporations, they are yet to translate such feats into constructing critical political culture and strategies in the production of "common goods" for the entire society rather than for an exclusive privileged Pentecostal class, a situation that mitigates against 
their narratives of effectiveness as instruments and institutions of social reform and transformation.

\section{References}

Acolatse, E. 2018. "Foreword" of S.C. Ilo, ed, Wealth, Health, and Hope in African Christian Religion: The Search for Abundant Life. New York: Lexington Books. ix-xii.

Asamoah-Gyadu, J.K. 2015. "Doing Greater Things: Mega Church as an African Phenomenon." In J.D. James, ed, A Moving Faith: Mega Churches Go South. London: Sage Publications Ltd, 43-61.

Bible-Davids, R. 2009. Enoch Adeboye: Father of Nations. London: Biblos Publishers.

Chidester, D. 2018. Religion: Material Dynamics. California: University of California Press.

Cox, H. 2001 [1995]. Fire from Heaven: The Rise of Pentecostal Spirituality and the Reshaping of Religion in the Twenty-First Century. Cambridge, MA: Da Capo Press Book.

Drønen, T.S. 2013. Pentecostalism, Globalisation, and Islam in Northern Cameroon: Megachurches in the Making? Leiden: Brill.

Dubois, F.M. 1978. How Churches Grow in an Urban World. Nashville: Boardman Press.

Ellington, S. 2010. "New Research on Megachurches: Non-Denominationalism and Sectarianism." In B.S. Turner, ed, The New Blackwell Companion to the Sociology of Religion. West Sussex: Blackwell Publishers, 247-266.

Ellington, S. 2013. "Packaging Religious Experience, Selling Modular Religion: Explaining the Emergence and Expansion of Megachurches." In F. Gauthier and T. Maritikainen, eds, Religion in Consumer Society: Brands, Consumers and Markets, Surrey, U.K: Ashgate Publishers, 59-73.

Frahm-Arp, M. 2016. "The Rise of the Megachurches in South Africa". In V. Synan, J.K. Asamoah-Gyadu and A. Yong, eds, Global Renewal Christianity: Spirit-Empowered Movements Past, Present, and Future. vol. III: Africa. Lake Mary, Fla.: Charisma House Publishers, 263-284.

Garrard-Burnett, V. 2015. "Foreword" for J.D. James, ed, A Moving Faith: Mega Churches Go South. London: Sage Publications Ltd, ix-xiii.

Gitau, W. M. 2018. Megachurch Christianity Reconsidered: Millennials and Social Change in African Perspective, Illinois: IVP Academic.

Ihejirika, W. C and Okon G.B. 2015. "Mega Churches and Megaphones: Nigerian Church Leaders and Their Media Ministries." In J.D. James, ed, A Moving Faith:Mega Churches Go South. London: Sage Publications Ltd, 62-82.

Innaccone, L.R., Olson D.V.A and R. Stark. 1995. "Religious Resources and Church Growth." Social Force, 74: 2, 705-731. 
James, J.D. 2015. “A Moving Faith: An Introduction”. In J.D. James, ed, A Moving Faith: Mega Churches Go South. London: Sage Publications Ltd, 1-17.

Jenkins, P. 2006. The New Faces of Christianity: Believing the Bible in the Global South. Oxford: Oxford University Press.

Jenkins, P. 2016. "How Africa is Changing Faith Around the World", http://trend. pewtrusts.org/en/archive/trend-summer-2016/how-africa-is-changing-faitharound-the-world. Accessed 31/08/18.

Kalu, O. 2008. African Pentecostalism: An Introduction. Oxford: Oxford university Press.

Morgan, D. 2018. Images at work: The material Culture of Enchantment. New York: Oxford University Press.

Ojo, M.A. 2006. The End-Time Army: Charismatic Movements in Modern Nigeria. Trenton: NJ: Africa world Press.

Onishi, N. 1998. "Lagos Journal; After Carnival of 'Second coming', An Apocalypse." The New York Times, December 8, https://www.nytimes.com/1998/12/o8/world/ lagos-journal-after-carnival-of-second-coming-an-apocalypse.html. Accessed $07 / 07 / 18$.

Oyedepo, D.O. 1997. Understanding Financial Prosperity. Lagos: Dominion Publishing House.

Oyedepo, D.O. 2008. Pillars of Destiny: Exploring the Secrets of an Ever-Winning Life. Lagos: Dominion Publishing House.

Peel, J. D. Y. 1968. Aladura: A Religious Movement among the Yoruba, London: Oxford University Press for the International African Institute.

Peel, J.D.Y. 2016. Christianity, Islam, and Orișa Religion: Three Traditions in Comparison and Interaction. California: University of California Press.

Riesebrodt, M. 2010. The Promise of Salvation: A Theory of Religion, trans. by Steven Rendall. Chicago: University of Chicago Press.

Sithole, I. 2016. Isaiah Shembe's Hymns and the Sacred Dance in Ibandla LamaNazaretha. Leiden: Brill.

Smith, J. 2008. "Public". In D. Morgan, ed, Keywords in Religion, Media and Culture. New York: Routledge, 148-159.

Ukah, A. 2008. A New Paradigm of Pentecostal Power: The Redeemed Christian Church of God in Nigeria. New Jersey: Africa World Press.

Ukah, A. 2012. "Mediating Armageddon: Popular Christian Video-Films as a Source of Conflict in Nigeria". In: J.H. Smith and R.I.J. Hackett, eds, Displacing the State: Religion and Conflict in Neoliberal Africa. Notre Dame: University of Notre Dame Press, 209-239.

Ukah, A. 2016a. "Building God's City: The Political Economy of Prayer Camps in Nigeria." International Journal of Urban and Regional Studies, 40:3, 524-540. 
Ukah, A. 2016b. "Prophecy, Miracle and Tragedy: The Afterlife of T.B. Joshua and the Nigerian State". In P. Coertzen, M.C. Green, and L. Hansen, eds, Religious Freedom and Religious Pluralism in Africa: Prospects and Limitations. Stellenbosch: SUN PReSS, 209-232.

Ukah, A. 2018. "Emplacing God: The Social Worlds of Miracle Cities-Perspectives from Nigeria and Uganda." Journal of Contemporary African Studies, DOI: 10.1080/ 02589001. 2018.1492094.

Ukah, A. and Echtler, M. 2009. "Born Again Witches and Videos in Nigeria". In D. Westerlund, ed, Global Pentecostalism: Encounters with Other Religious Traditions. London and New York: I.B. Tauris \& Co Ltd, 73-92.

Ukpabio, H. 1999. The Seat of Satan Exposed. 3rd ed., Calabar: Liberty Foundation Gospel Ministries.

Van Wyk, I. 2014. The Universal Church of the Kingdom of God in South Africa: A Church of Strangers. Cambridge: Cambridge University Press.

Weber, M. 1992 [1922]. The Sociology of Religion, trans. Ephraim Fischoff. Boston, MA: Beacon Press. 